\title{
Impact of Plow Timing on Simultaneous Nitrogen Losses in Potato Production Systems Using Conventional Tillage Practices
}

\author{
E. L. Smith ${ }^{1}$, A. $\operatorname{Vosman}^{2}$, V. $\operatorname{Rodd}^{3} \&$ L. Kellman ${ }^{2}$ \\ ${ }^{1}$ Agriculture and Agri-Food Canada, Truro, Nova Scotia, Canada \\ ${ }^{2}$ St. Francis Xavier University, Antigonish, Nova Scotia, Canada \\ ${ }^{3}$ Agriculture and Agri-Food Canada, Charlottetown, Prince Edward Island, Canada \\ Correspondence: E. L. Smith, Agriculture and Agri-Food Canada, 361 Pictou Road, Truro, Nova Scotia, Canada. \\ E-mail: erin.smith2@canada.ca
}

Received: October 15, 2018

Accepted: November 23, $2018 \quad$ Online Published: January 15, 2019

doi:10.5539/jas.v11n2p12

URL: https://doi.org/10.5539/jas.v11n2p12

\begin{abstract}
Improving plowing management of high nitrogen $(\mathrm{N})$ containing crops is essential in reducing both environmental and economic losses. The timing of plowing may be an important soil and nutrient conservation practice. A field study on a 3 yr potato rotation was conducted in Prince Edward Island, Canada to examine the

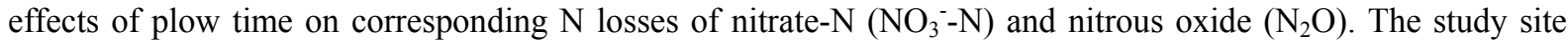
consisted of nine tile drained plots (12 m spacing) with three treatments of plow time; early fall (EF), late fall (LF) temperature based, and the following spring (S) plow. The cropping rotations consisted of barley under-seeded with red clover in yr 1, red clover in yr 2, and Russet Burbank potatoes in yr 3. Each tile drained plot fed into a sample collection station where $50 \mathrm{~mL}$ water samples were obtained during flow events and analyzed for $\mathrm{NO}_{3}{ }^{-}-\mathrm{N}$. Nitrous oxide samples were also simultaneously obtained from the soil surface throughout the monitoring period using a static chamber methodology. Cumulative $\mathrm{NO}_{3}{ }^{-} \mathrm{N}$ loads over the 3 yrs were found to be reduced at 14.3 and $19.9 \mathrm{~kg} \mathrm{ha}^{-1}$ for LF and $\mathrm{S}$ respectively, when compared to the EF plow at $24.4 \mathrm{~kg} \mathrm{ha}^{-1}$. Nitrous oxide losses were variable and low in magnitude throughout the study $(0.04-1.2 \%$ of the $\mathrm{N}$ applied). Overall, findings from this research suggest that the timing of plowing could be considered when trying to minimize $\mathrm{N}$ losses via tile drainage effluent. When considering $\mathrm{NO}_{3}{ }^{-}-\mathrm{N}$ total loads during the rotation period, $\mathrm{LF}$ had reduced losses compared to EF in all years of the study. Late fall reduced $\mathrm{N}_{2} \mathrm{O}$ losses in 1 year by $38.2 \%$ compared to S, likely due the incorporation of red clover legume crop. Yields were found to be similar throughout treatments and cropping years, although LF was found to have 2 and 3 -fold significant increases in yield of $10 \mathrm{oz}$ potatoes vs. EF and $\mathrm{S}$, respectively. Findings generated from this study will provide nutrient management and environmental farm planners, as well as producers with useful information for improving current management strategies within agricultural drainage systems.
\end{abstract}

Keywords: water quality, greenhouse gas emissions, nitrogen loss, plow timing, potatoes

\section{Introduction}

The potato is the largest cash crop in Prince Edward Island (PEI), worth over \$1B to the island economy, subsequently making PEI the largest potato-producing province in Canada growing over $25 \%$ of the country's potatoes (PEI Potato Board 2018). The PEI Department of Agriculture (2015) requires a 3 yr rotation when growing potatoes (Solanum tuberosum) to minimize environmental impacts and maintain soil quality. One typical rotation practiced is barley (Hordeum vulgare) under-seeded to red clover (Trifolium pretense) (yr 1), red clover (yr 2) and then potatoes (yr 3). The plowing of the red clover in preparation for the potato year is typically done in the fall.

Tillage systems are not definitive and vary widely between soil type, crop, climate and producer (Agriculture and Agri-Food Canada, 2014). Plowing breaks up the soil, disrupts weed growth, and improves soil aeration. Moldboard plowing is a conventional method that has been practiced for well over a century (Reicosky, 2006) where rows of land are turned over, exposing bare soil. With this method crop yields are typically higher than with less intensive practices (Camara et al., 2003).

Conventional plowing exposes soils to water and wind erosion further escalating the potential of $\mathrm{N}$ losses 
through leaching $\left(\mathrm{NO}_{3}{ }^{-}\right)$, surface runoff and volatilization $\left(\mathrm{N}_{2} \mathrm{O}, \mathrm{NO}, \mathrm{N}_{2}\right)$. Furthermore, organic and inorganic $\mathrm{N}$ inputs are commonly incorporated into cropping systems to improve yields. However, an oversupply of inputs is a contributing factor to the disruption of the natural biogeochemical cycle leading to $\mathrm{N}$ losses (Schlesinger \& Bernhardt, 2013). Due to the resistance of $\mathrm{NO}_{3}{ }^{-} \mathrm{N}$ to bond with negative soil particles coupled with its high water-solubility, the potential of leaching to surface or groundwater sources is augmented when excessive amounts are present and exceed plant requirements (Lamb et al., 2014).

Nitrous oxide $\left(\mathrm{N}_{2} \mathrm{O}\right)$ is approximately 300 times more potent a greenhouse gas than carbon dioxide (Myhre et al., 2013) and the most destructive substance responsible for depleting the stratospheric ozone layer (Butterbach-Bahl et al., 2013). Emissions of $\mathrm{N}_{2} \mathrm{O}$ from agricultural soils account for 3\% of the anthropogenic sources in Canada (Environment and Climate Change Canada, 2017). Soil respiration causes N losses through nitrification or denitrification as part of the $\mathrm{N}$ cycle (Schelesinger \& Bernhardt, 2013). Nitrification requires sufficient supplies of ammonium $\left(\mathrm{NH}_{4}^{+}\right)$substrate, either as an input of fertilizer, or naturally mineralized from an organic matter source (i.e. crop residue) to initiate the process (Schelesinger \& Bernhardt, 2013).

The production of $\mathrm{N}_{2} \mathrm{O}$ through the process of denitrification is more widely investigated as this pathway is often reported as the leading source (Xue et al., 2013). Denitrification occurs under anoxic soil conditions where free oxygen is lacking but bound oxygen is available to initiate the pathway (Elmi et al., 2005). Therefore, soil with a higher moisture content may accelerate denitrification processes. Microbial bacteria require $\mathrm{NO}_{3}{ }^{-}$or another oxidized form of $\mathrm{N}$ substrate as the electron acceptor in the first step of the reduction pathway (Robertson, 2014). Reductase enzymes are required in each step to reduce further and therefore a lack of or delayed production of a certain enzyme can lead to the release of that substrate into the environment (Robertson, 2014). During the reduction of nitric oxide (NO), $\mathrm{N}_{2} \mathrm{O}$ is a possible by-product that can be released into the environment (Butterbach-Bahl et al., 2013). Furthermore, $\mathrm{N}_{2} \mathrm{O}$ has the ability to further reduce to $\mathrm{N}_{2}$, which has no detrimental effects to the environment or ozone layer (Blackmer \& Bremner, 1978) as the atmosphere contains $78 \% \mathrm{~N}_{2}$.

Farmers make decisions about timing of tillage, post-harvest or prior to planting (i.e. fall vs. spring) based on varying factors. Spring plowing may conflict with other spring activities such as seeding, especially when there are weather delays. Some farmers have indicated that plowing under wet conditions in the spring could result in massive soil aggregates (clods), which in turn could impede the fall harvesting of potatoes. Also, residue of the incorporated crop may not be decomposed sufficiently, thus interfering with the planting and harvesting of the subsequent crop, especially root and tuber crops. A benefit to fall plowing may be that conditions are drier compared to the spring when fields are likely more saturated. However, Rasouli et al. (2014) stated that lower temperatures, mixed with high saturation and low evapotranspiration rates could elevate the risk of $\mathrm{N}$ losses via air and water. Risk of $\mathrm{N}$ loss is heightened in the late fall and spring when these conditions are more probable. Plowing is a time-consuming task; farmers typically have more available time in the fall compared to the spring. Adversely, fall tillage removes a cover crop for the winter season leading to vulnerability of leaching, potential gaseous and yield losses such as $\mathrm{N}_{2} \mathrm{O}$. Legume crops can supply an important source of $\mathrm{N}$ requirements for successive crops and delaying plow could lead to more efficient use of mineralized crop residues. In the Tennessee Valley Region of North Alabama, Raper et al. (2000) reported statistically higher cotton yields in 3 out of 4 yrs when using a cover crop. Additionally, Sanderson et al. (1999) found in one year of a 3 yr study that spring moldboard plowing of red clover required less $\mathrm{N}$ inputs to sustain higher yields of a potato crop compared with an early fall plow with higher $\mathrm{N}$ inputs. Yost et al. (2012) found that alfalfa grown in the year prior could satisfy the $\mathrm{N}$ nutritional requirements of corn.

Di and Cameron (2002) found that the most susceptible period of leaching in temperate regions is following harvest during the fall and winter seasons. Fall plowing on PEI is an activity typically running from September to the end of October/beginning of November with corresponding temperatures decreasing during this period from 20 to $5{ }^{\circ} \mathrm{C}$ (Environment and Climate Change Canada, 2018). Early in this period, microbial activity is heightened with the reduction of evapotranspiration and increased soil moisture, leading to mineralized forms of organic N (Di \& Cameron, 2002). By delaying plowing until late in the fall mineralization could be reduced, as would the potential for nitrate leaching. Delaying plow and/or herbicidal termination of forages to the spring helped in reducing $\mathrm{NO}_{3}{ }^{-} \mathrm{N}$ leaching according to Jiang et al. (2015). Following this practice, Jiang et al. (2015) suggested a spring plow had reduced leaching by $20-60 \%$ compared to fall plow (early Nov.) in a paired experiment conducted on PEI. Jiang et al. (2015) proposed the elevated fall leaching was due to mineralization of crop residues. In a lab study, Malhi et al. (1990) concluded that soil under a saturated environment with increasing temperature $\left(<60{ }^{\circ} \mathrm{C}\right)$ resulted in $\mathrm{NO}_{3}{ }^{-}-\mathrm{N}$ losses, with the highest loss found at the $4-10{ }^{\circ} \mathrm{C}$ range. This suggested that periods of warming temperature and high soil saturation may provide favorable conditions 
for $\mathrm{NO}_{3}{ }^{-} \mathrm{N}$ losses (Malhi et al., 1990), similar to spring conditions in Atlantic Canada.

High annual precipitation in the Atlantic Canada region has led to the adoption of drainage systems to remove excess water from agricultural land in a timely manner. Gartley et al. (1986) estimated that the Atlantic Provinces received $50 \%$ excess water for crop requirements based on an average of $1000 \mathrm{~mm}$ annually. Artificial subsurface drainage is a common mechanism used to efficiently remove excess water from imperfectly drained agricultural fields. However, as these systems drop the water table at an accelerated rate, they also have the capacity to flush nutrients into surface waters (Smith \& Kellman, 2011).

Fall tillage can create the potential for $\mathrm{NO}_{3}^{-}-\mathrm{N}$ leaching and gaseous $\mathrm{N}_{2} \mathrm{O}$ losses. Current strategies to reduce $\mathrm{N}$ losses from agricultural fields have been site specific and in some cases have been shown to enhance greenhouse gas production. It is therefore important to also examine any potential trade-off effects that may exist between $\mathrm{NO}_{3}{ }^{-}-\mathrm{N}$ and $\mathrm{N}_{2} \mathrm{O}$ losses before making recommendations regarding on-farm management practices. Studies investigating simultaneous losses of $\mathrm{N}$ from different temperature and seasonal based plow times are limited. The purpose of this study was therefore to evaluate the simultaneous losses of $\mathrm{NO}_{3}^{-}-\mathrm{N}$ and $\mathrm{N}_{2} \mathrm{O}$ from a 3 yr rotation potato production system using three different plow times for incorporation of the red clover prior to potatoes; early fall (EF), late fall (LF) and spring (S) to determine improved management strategies in terms of minimizing overall $\mathrm{N}$ losses.

\section{Materials and Methods}

\subsection{Site Description}

This research study was conducted at the Water Quality Site at Agriculture Agri-Food Canada's (AAFC) Research Farm in Harrington, PEI $\left(46^{\circ} 20^{\prime} \mathrm{N}, 63^{\circ} 10^{\prime} \mathrm{W}\right)$. Soil at the research site was a sandy loam acidic (pH 5.8-6.1) Charlottetown soil classified as an Ortho Humo-Ferric Podzol (MacDougall et al., 1988). Total growing season precipitation amounts for each cropping year were; 672, 631 and $561 \mathrm{~mm}$ for 2015-2017, respectively; corresponding to reduced precipitation amounts compared to the 30 yr normal (1981-2010) with 13, 18 and 27\% less for yr 1 (2015), yr 2 (2016) and yr 3 (2017), respectively. A summary of the average climate data for all cropping years can be found in Table 1. At this site there were nine tile drained plots 44 by $95 \mathrm{~m}$ (Figure 1). Within each plot there were two tile lines at an approximate depth of $0.80 \mathrm{~m}$; lines are joined together and subsequently flowed into a sampling station where tile flow measurements were collected during the cropping seasons (Apr. 1-Nov. 30, 2015-2017) using a Hobo and ACR data loggers. Additionally, buffer tile lines at the edges of the plots ensured that the plots were hydrostatically separated. Plots at the study area were plowed with $\mathrm{EF}, \mathrm{LF}$ and $\mathrm{S}$ treatments occurring prior to potatoes within the $3 \mathrm{yr}$ rotation of barley under-seeded to red clover (yr 1), red clover (yr 2) and then potatoes (yr 3). Plots, which at the time consisted of red clover (yr 2 of the three year potato rotation) were plowed using a four furrow Kuhn rollover moldboard plow in EF, LF and the following $\mathrm{S}$ treatments occurring prior to potatoes within the $3 \mathrm{yr}$ rotation. Late fall plowing occurred when the soil temperature at a $10 \mathrm{~cm}$ soil depth reached an average of $7^{\circ} \mathrm{C}$ for 5 consecutive days. 
Table 1. Average air temperature $\left({ }^{\circ} \mathrm{C}\right)$ and total precipitation $(\mathrm{mm})$ for the Agriculture and Agri-Food Canada's Water Quality Site in Harrington, PEI for the 2015-2017 cropping seasons (Apr.-Nov.)

\begin{tabular}{|c|c|c|c|}
\hline Year & Month & Avg. Air Temperature $\left({ }^{\circ} \mathrm{C}\right)$ & Total Precipitation (mm) \\
\hline \multirow[t]{8}{*}{2015} & Apr. & 0 & 182.4 \\
\hline & May & 10.7 & 86.0 \\
\hline & Jun. & 13.0 & 111.5 \\
\hline & Jul. & 18.0 & 36.7 \\
\hline & Aug. & 21.0 & 115.6 \\
\hline & Sept. & 16.4 & 67.9 \\
\hline & Oct. & 8.0 & 112.9 \\
\hline & Nov. & 4.5 & 141.3 \\
\hline \multirow[t]{8}{*}{2016} & Apr. & 2.2 & 74.3 \\
\hline & May & 9.5 & 57.0 \\
\hline & Jun. & 14.6 & 72.0 \\
\hline & Jul. & 18.9 & 39.4 \\
\hline & Aug. & 18.5 & 134.8 \\
\hline & Sept. & 15.3 & 68.0 \\
\hline & Oct. & 9.9 & 136.2 \\
\hline & Nov. & 4.7 & 123.7 \\
\hline \multirow[t]{8}{*}{2017} & Apr. & 4.1 & 40.9 \\
\hline & May & 9.4 & 115.9 \\
\hline & Jun. & 15.6 & 75.3 \\
\hline & Jul. & 18.6 & 42.6 \\
\hline & Aug. & 18.2 & 99.2 \\
\hline & Sept. & 15.6 & 56.5 \\
\hline & Oct. & 11.6 & 1.2 \\
\hline & Nov. & 4.5 & 99.2 \\
\hline
\end{tabular}

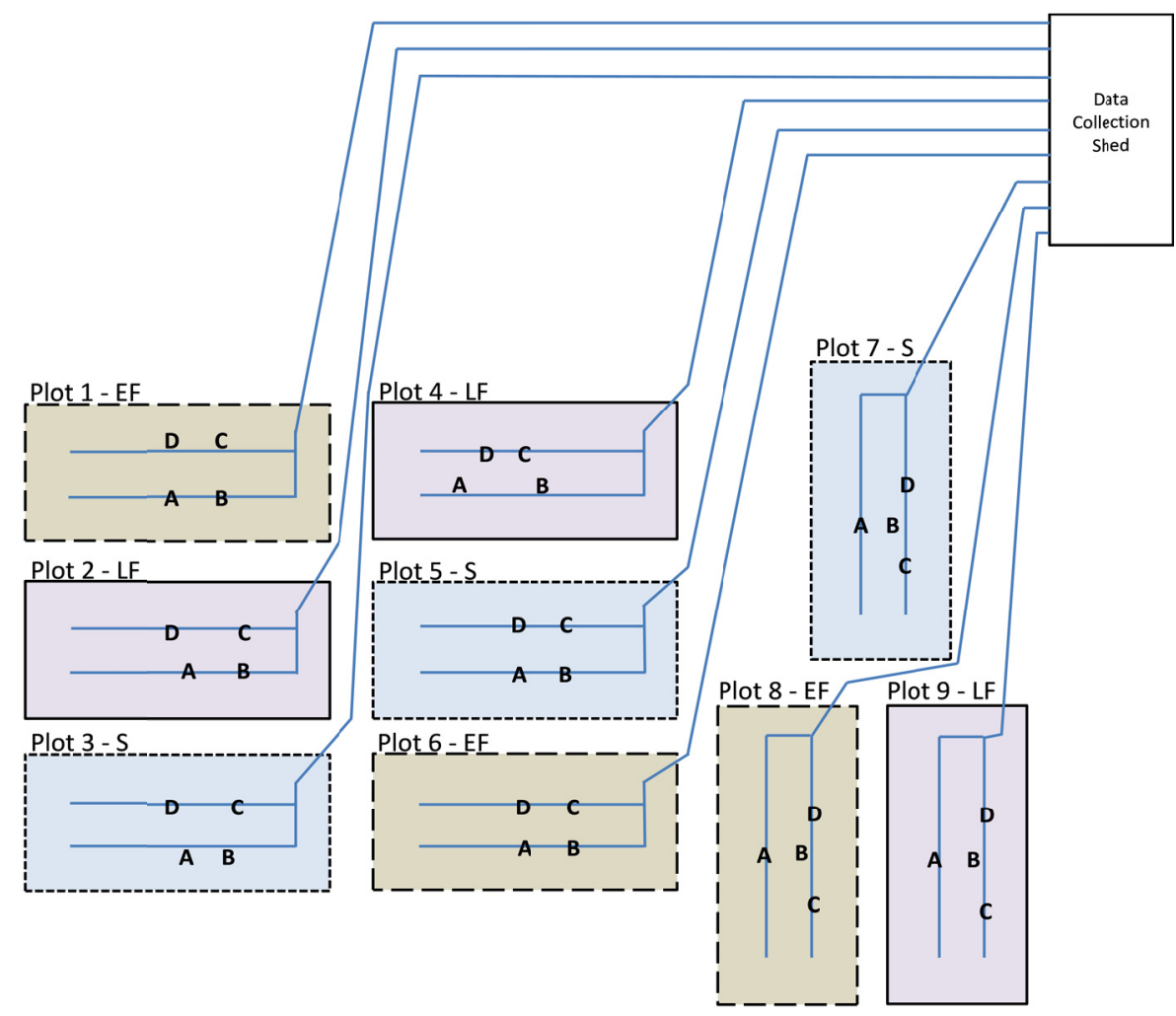

Figure 1. Schematic of the Water Quality Site located at Agriculture and Agri-Food Canada's Research Farm in Harrington, PEI, with early fall (EF) (plots 1, 6, 8), late fall (LF) (plots 2, 4, 9) and spring (S) (plots 3, 5, 7) plow treatments. Each plot contained separate tile lines which flowed into a data collection shed to allow for individual samples. Nitrous oxide samples were collected at the A, B, C and D locations within each plot 
Field activities including; plow times, rotation crops, inputs and harvest over the research period (2015-2017) are found in Table 2. The drainage plots were seeded with barley under-seeded with red clover in yr 1, yr 2 consisted of red clover, and Russet Burbank potatoes were planted in yr 3. There was no manure applied in the cropping years studied. The following sprays were however used; in 2015 the herbicide MCPA ${ }^{\circledR}$ (Ester 300) was used to control the weeds in the barley, no sprays were used in 2016 while in red clover, and in 2017 when in potatoes the herbicides Sencor ${ }^{\circledR}$ and Prisim, the fungicide Bravo, and the top-killer Reglone were used.

Table 2. A summary of field activities for a 3-year potato rotation system using early fall (EF), late fall (LF) and spring (S) plowing, located at Agriculture and Agri-Food Canada's Drainage Site in Harrington, PEI

\begin{tabular}{llll}
\hline Parameter & Year 1 & Year 2 & Year 3 \\
\hline Crop & Island barley under-seeded w/red clover & Red clover & Russet Burbank potato \\
Fertilizer & $224 \mathrm{~kg} \mathrm{ha}^{-1}(15-15-15)$ & None & $100 \mathrm{~kg} \mathrm{~N} \mathrm{ha}^{-1}$ \\
Planting date & Jun. 2 & Red clover re-growth & May 31 \\
Harvest date & Aug. 31 & Flailed Jun. 21 & Oct. 18 \\
S plow & NA & NA & May 3 \\
EF plow & NA & Oct. 6 & NA \\
LF plow & NA & Nov. 17 & NA \\
\hline
\end{tabular}

Note. *NA is not applicable.

\subsection{Gas Sampling}

Gas samples were collected at the drainage site throughout the cropping seasons (approximately every 2-3 wks, as well as following field activities). Sampling was conducted following the static chamber methodology described by Smith et al. (2008). Four polyvinyl chloride (PVC) collars were installed in each plot at least 24 hrs prior to gas collection. Early installation was important before sampling to prevent lateral flow of gases within the system (Collier et al., 2014). Chambers were insulated with a reflective material to avoid overheating during sampling and vented to avoid changes in pressure from the surrounding environment (Collier et al., 2014).

Environmental parameters such as; soil moisture, soil and air temperature, and relative humidity were measured using probes during each sample period immediately prior to gas collection. Chamber and collar heights were also recorded at the time of sampling at each sample location to allow for the flux calculation as defined by Snowdon et al. (2013). Gas samples were collected at three time intervals; 0, 15 and $30 \mathrm{~min}$ at each collar with a one minute interval between chambers. Samples were collected using a $20 \mathrm{~mL}$ polypropylene syringe and Luer-Lok $^{\circledR}$ tip needles (25 gauge, $1.5875 \mathrm{~cm}$ in length). Syringes were purged several times between each sample to avoid cross contamination. Gas samples were collected from each chamber and injected into a $12 \mathrm{~mL}$ Labco $^{\circledR}$ exetainer (Labco International, UK) with a rubber septa and silicone cover to avoid gas leakage. Vials were pre-evacuated following a series of flushings with helium and evacuated with the aid of a vacuum pump. After collection, vials were stored in a cool area until analysis using gas chromatography (GC).

A Varian Star 3800 GC (Agilent Technologies, Inc., Walnut Creek, CA) was utilized to measure $\mathrm{N}_{2} \mathrm{O}$. Quality control was sustained by running predetermined increasing concentrations $(0,0.5$ and $1.5 \mathrm{ppm})$ of standard gas $\left(\mathrm{N}_{2} \mathrm{O}\right)$. The auto-sampler extracted $2.5 \mathrm{~mL}$ of gas sample from each exetainer and injected into the heated injection port. A portion of this extraction $(0.5 \mathrm{~mL})$ was utilized for $\mathrm{N}_{2} \mathrm{O}$ analysis and carried through the column (mobile phase) with an inert mixture of $90 \%$ argon and $10 \%$ methane $\left(\mathrm{CH}_{4}\right)$ gas. The subsample $(0.5 \mathrm{~mL})$ analyzed for $\mathrm{N}_{2} \mathrm{O}$ content ran through the column oven (maintained at $70{ }^{\circ} \mathrm{C}$ ) and then moved to the electron captor detector (ECD) held at a temperature of $300^{\circ} \mathrm{C}$.

\subsection{Nitrate- $N$ Sampling}

Water samples were collected from the tile line in each plot during periods of flow throughout the cropping seasons (Apr. 1-Nov. 30, 2015-2017). Calibrated tipping buckets for each plot were installed at the end of each tile line in the sampling station to measure hourly outflow (Figure 1). Water samples $(300 \mathrm{~mL})$ were collected by ISCO 6712 samplers (4700 Superior Street NE 68504, USA) directly from each tipping bucket during periods of continuous flow (i.e. following a rainfall event or snow melt) and later transferred to $50 \mathrm{~mL}$ high density, polyethylene containers. Samples were kept cool $\left(4{ }^{\circ} \mathrm{C}\right)$ and later analyzed for $\mathrm{NO}_{3}{ }^{-} \mathrm{N}$ concentrations. Nitrate-nitrogen analysis was conducted using a Lachat QuikChem 8500 flow injection analyzer (Lachat Instruments, Loveland, $\mathrm{CO}$ ) following the colorimetric methodology. Total loads $\left(\mathrm{kg} \mathrm{ha}^{-1}\right)$ for each drainage 
system during each cropping year were calculated by multiplying the total flow for a day (L) by the daily concentration and dividing by the tile drained area.

\subsection{Yields}

In 2015 barley was seeded with a conventional grain drill and managed conventionally throughout the growing season. When ripe, random areas within the drainage plots were harvested with a Wintersteiger plot combine (964 Bergar Street, Laval QC H7L 5A1). The harvested grain was then bagged and dried to 13\% moisture (trade moisture level), cleaned and weighed and yield per hectare was calculated. Prior to plowing the red clover, the red clover biomass on each plot was determined. At each plot all the above ground biomass was removed from two random square meter quadrants. This material was then weighed and a subsample was dried at $45^{\circ} \mathrm{C}$ for 48 hrs. Once the dry matter of the material in the subsample was known, then the dry matter of the plot was determined. Using the total known dry matter and amount of $\mathrm{N}$, the red clover $\mathrm{N}$ credit prior to plow down was calculated. In 2017, once the potatoes had matured (approx. $21 \mathrm{~d}$ post top kill), and the skin on the potato tuber was sufficient so that it was not going to be damaged by mechanical harvesting, the crop was harvested. Two 15 $\mathrm{m}$ strips were mechanically harvested with a 1 row Grimme Harvester (Grimme UK Ltd., Station Road Swineshead, Boston, Lincolnshire, England, PE20 3PS), bagged and put in storage until graded and yields were calculated.

Treatment differences were determined using ANOVA (Minitab, 2008), meeting the assumption of normality and constant variance. Transformations were conducted on the loading when required and means of treatments were compared (probability level of 0.05 ).

\section{Results and Discussion}

\subsection{Nitrate- $N$ Concentrations and Loads}

Average $\mathrm{NO}_{3}^{-}-\mathrm{N}$ concentrations and corresponding total daily flow are shown in Figure 2. Daily flows for each plow time followed similar patterns (Figure 2) throughout all years of study. Nitrate-N concentrations for the most part were positively correlated to flow rates for all plow times (Figure 2), which is consistent with previous studies (Gilliam et al., 1979; Gordon et al., 2000; Wesström \& Messing, 2007; Sands et al., 2008; Smith \& Kellman, 2011). Nitrate-N concentrations were variable $(\mathrm{P}<0.05)$ throughout the study period ranging from $\mathrm{EF}$ : 4.5-17.9, LF: 4.6-24.2 and S: $3.5-17.0 \mathrm{mg} \mathrm{L}^{-1}$ for 2015; EF: $1.8-15.6$ and LF: $2.2-6.8$ and $\mathrm{S}: 1.1-5.2 \mathrm{mg} \mathrm{L}^{-1}$ for 2016; and EF: 4.9-29.9, LF: 2.8-30.0 and S: $2.7-33.2 \mathrm{mg} \mathrm{L}^{-1}$ for 2017. Nitrate-N concentrations were lower at the start of the season and increased steadily following fertilizer applications in 2015 and 2017 as expected, as also found by Donner and Kucharik (2003), and Smith and Kellman (2011) in their studies, confirming the leaching potential for $\mathrm{NO}_{3}^{-}-\mathrm{N}$.

During yr $1, \mathrm{NO}_{3}^{-}-\mathrm{N}$ concentrations were above the Canadian Drinking Water Quality Guideline of $10 \mathrm{mg} \mathrm{L}^{-1}$ (Health Canada, 2015) with EF: 61, LF: 55 and S: $43 \%$ of the time in yr 1; EF: 8, LF: 0 and S: $0 \%$ of the time in yr 2; and EF: 37, LF: 24 and S: $0 \%$ of the time in yr 3. Periodic elevation of $\mathrm{NO}_{3}{ }^{-}-\mathrm{N}$ concentrations above the Canadian Drinking Water Quality Guideline indicate tile drainage systems need to be closely monitored (Health Canada, 2015). The elevated $\mathrm{NO}_{3}{ }^{-}-\mathrm{N}$ concentrations obtained in the present study, therefore supports the finding that agricultural tile drainage does have the potential to contribute $\mathrm{NO}_{3}{ }^{-}-\mathrm{N}$ loadings into aquatic systems. These findings were also supported by Smith and Kellman (2011), Kellman (2005), Tomer et al. (2003), Galloway and Cowling (2002), Jaynes et al. (2001), and Randall and Iragavarapu (1995).

Loads of $\mathrm{NO}_{3}{ }^{-}-\mathrm{N}$ exiting the drainage systems over the monitoring periods were; EF: 7.5, LF: 4.9 and S: $7.6 \mathrm{~kg}$ ha $^{-1}$ in yr 1; EF: 5.2, LF: 1.7 and S: $2.3 \mathrm{~kg} \mathrm{ha}^{-1}$ in yr 2; and EF: 11.7, LF: 7.7 and S: $10.0 \mathrm{~kg} \mathrm{ha}^{-1}$ in yr 3 (Table 3). Total $\mathrm{NO}_{3}^{-}-\mathrm{N}$ loads for the three growing seasons in the rotation were $14.3 \mathrm{~kg} \mathrm{ha}^{-1}$ for LF and $19.9 \mathrm{~kg} \mathrm{ha}^{-1}$ for S, compared to the EF plow plots at $24.4 \mathrm{~kg} \mathrm{ha}^{-1}$. This represented a reduction of 41.4 and $18.5 \%$ in total $\mathrm{NO}_{3}{ }^{-} \mathrm{N}$ loads, for $\mathrm{LF}$ and $\mathrm{S}$, respectively. The increase in $\mathrm{NO}_{3}{ }^{-} \mathrm{N}$ in the EF plots was most likely attributable to the higher air and soil temperature, as well as the reduced soil moisture compared to the other plow treatments. In addition, these higher temperatures also allowed for mineralization to not only occur, but to occur over an extended period compared to the other plow treatments before the next year's crop was established. Results in the present study were similar to a 3 yr potato study of Jiang et al. (2015) who found that $\mathrm{NO}_{3}{ }^{-} \mathrm{N}$ leaching in sandy loam soils in PEI under potato production were reduced by $20-60 \%$ from shallow and ground water when a spring plow was used in combination with a spring herbicide application when compared to fall plow. The present study found reductions of 55.8 and $14.6 \%$ in $\mathrm{NO}_{3}{ }^{-} \mathrm{N}$ loading when considering S vs EF plowing in yr 2 and 3, respectively. However, contrary to these findings of Jiang et al. (2015), year 1 of the present study found $\mathrm{LF}$ to reduce $\mathrm{NO}_{3}^{-}-\mathrm{N}$ loading by $36 \%$ when compared to $\mathrm{S}$ plow in year 1 of the study. It appears that from a $\mathrm{NO}_{3}{ }^{-}-\mathrm{N}$ loading perspective EF plowing was not desirable. These findings are also consistent with those of 
Sanderson et al. (1999) who found reduced N losses when plowing after mid-October compared to a mid-September plow. Shepard et al. (1993) suggested leaving the land fallow after harvest with no cultivation was better than plowing and drilling a crop late in the fall when $\mathrm{NO}_{3}{ }^{-}-\mathrm{N}$ risk is heightened.

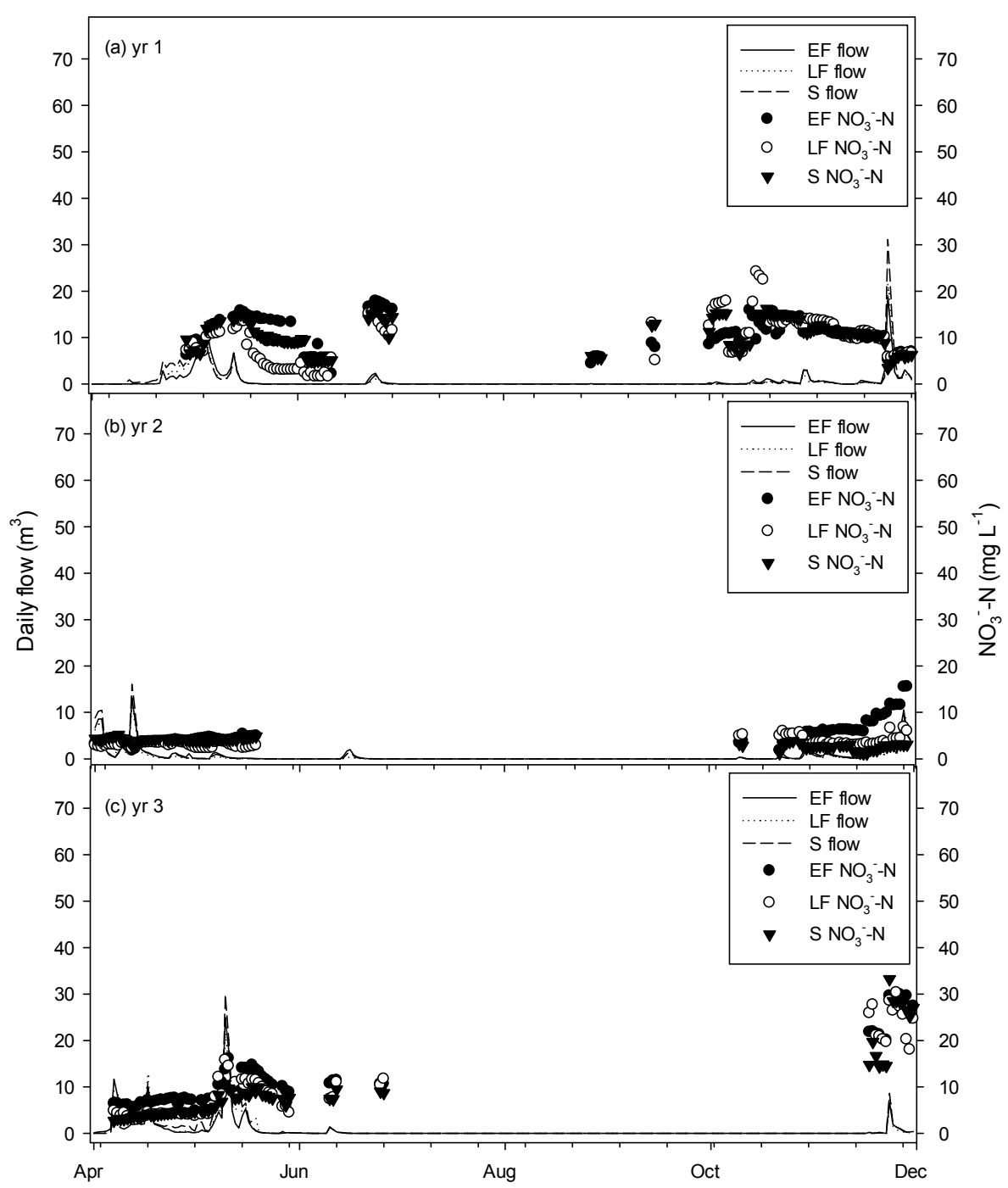

Figure 2. Daily flow $\left(\mathrm{m}^{3}\right)$ and corresponding nitrate-N $\left(\mathrm{NO}_{3}{ }^{-}-\mathrm{N}\right)$ concentrations for early fall (EF), late fall (LF) and spring (S) plow treatments for the study periods of Apr. $1^{\text {st }}-$ Nov. $30^{\text {th }}$ in (a) yr 1, (b) yr 2 and (c) yr 3 located at the Water Quality Site on Agriculture and Agri-Food Canada's Research Farm in Harrington, PEI 
Table 3. Summary of total and averaged nitrate- $\mathrm{N}\left(\mathrm{NO}_{3}{ }^{-} \mathrm{N}\right)$ load and flow parameters measured for early fall (EF), late fall (LF) and spring (S) plow treatments during the period of Apr. $1^{\text {st }}$-Nov. $30^{\text {th }}$ in the three-year potato rotation system at Agriculture and Agri-Food Canada's Water Quality Site located at the Research Farm in Harrington, PEI

\begin{tabular}{|c|c|c|c|c|}
\hline Parameter & Rotation Year & $\mathbf{E F}$ & $\mathbf{L F}$ & $\mathbf{S}$ \\
\hline \multirow[t]{3}{*}{ Total flow $\left(\mathrm{m}^{3}\right)$} & Yr 1 & $168.9 \pm 2.2$ & $161.8 \pm 2.3$ & $206.0 \pm 2.9$ \\
\hline & Yr 2 & $154.2 \pm 1.7$ & $116.5 \pm 1.6$ & $147.9 \pm 1.9$ \\
\hline & Yr 3 & $177.5 \pm 2.5$ & $193.5 \pm 2.4$ & $192.2 \pm 2.8$ \\
\hline \multirow[t]{3}{*}{$\mathrm{NO}_{3}-\mathrm{N}$ total load $\left(\mathrm{kg} \mathrm{ha}^{-1}\right)^{\mathrm{z}}$} & Yr 1 & $7.5^{\mathrm{a}} \pm 0.09$ & $4.9^{6} \pm 0.07$ & $7.6^{a} \pm 0.10$ \\
\hline & Yr 2 & $5.2^{\mathrm{b}} \pm 0.09$ & $1.7^{\mathrm{a}} \pm 0.03$ & $2.3^{\mathrm{a}} \pm 0.03$ \\
\hline & Yr 3 & $11.7^{\mathrm{b}} \pm 0.21$ & $7.7^{\mathrm{a}} \pm 0.14$ & $10.0^{\mathrm{a}} \pm 0.20$ \\
\hline \multirow[t]{3}{*}{$\mathrm{NO}_{3}^{-}-\mathrm{N}\left(\mathrm{mg} \mathrm{L}^{-1}\right)$} & Yr 1 & $12.1 \pm 3.6$ & $11.8 \pm 6.2$ & $11.2 \pm 3.5$ \\
\hline & Yr 2 & $5.4 \pm 3.2$ & $3.5 \pm 1.8$ & $3.3 \pm 1.1$ \\
\hline & Yr 3 & $12.3 \pm 3.4$ & $10.3 \pm 3.8$ & $9.5 \pm 2.4$ \\
\hline \multirow[t]{3}{*}{$\mathrm{NO}_{3}^{-}-\mathrm{N}$ range $\left(\mathrm{mg} \mathrm{L}^{-1}\right)$} & Yr 1 & $4.5-17.9$ & $4.6-24.2$ & $3.5-17.0$ \\
\hline & Yr 2 & $1.8-15.6$ & $2.2-6.8$ & $1.1-5.2$ \\
\hline & Yr 3 & 4.9-29.9 & $2.8-30.0$ & $2.7-33.2$ \\
\hline
\end{tabular}

${ }^{\mathrm{z}}$ Numbers with the same letter are not significantly different at the probability level of 0.05 .

\subsection{Nitrous Oxide}

Nitrous oxide fluxes were variable throughout the study periods and generally low in magnitude with ranges of EF: $0.78-2.7$, LF: $0.82-2.7$ and S: $0.42-2.6 \mathrm{~g} \mathrm{~N} \mathrm{ha}^{-1} \mathrm{~d}^{-1}$ in yr 1; and EF: 0.27-0.41, LF: 0.02-0.87 and S: 0.12-0.4 $\mathrm{g} \mathrm{N} \mathrm{ha}^{-1} \mathrm{~d}^{-1}$ in yr 2; and EF: 0.09-4.4, LF: 0.12-4.36 and S: 0.5-8.37 $\mathrm{g} \mathrm{N} \mathrm{ha}^{-1} \mathrm{~d}^{-1}$ in yr 3 (Table 4). Lower fluxes may be attributable to the sandy loam soil at the study site allowing for more aerobic conditions. Lower precipitation amounts, than the $30 \mathrm{yr}$ normal in all 3 yrs of the study, could have also played a role as soil moisture levels were reduced therefore decreasing the opportunity for anaerobic conditions to occur.

Table 4. Summary of gaseous loss of nitrous oxide $\left(\mathrm{N}_{2} \mathrm{O}\right)$ for; early fall (EF), late fall (LF) and spring (S) plowing times during the periods of Apr. $1^{\text {st }}$-Nov. $30^{\text {th }}, 2015-2017$ at Agriculture and Agri-Food Canada's Water Quality Site located at the Harrington Research Farm, Harrington, PEI

\begin{tabular}{|c|c|c|c|}
\hline Rotation year and crop & Treatment $^{*}$ & $\mathrm{~N}_{2} \mathrm{O}$ total loss $\left(\mathrm{g} \mathrm{N} \mathrm{ha}^{-1}\right)^{\mathrm{z}}$ & $\mathrm{N}_{2} \mathrm{O}$ loss (\% $\mathrm{N}$ applied $)^{\mathrm{z}}$ \\
\hline Year 1 & $\mathrm{EF}$ & $16.4^{\mathrm{a}}$ & $0.05^{\mathrm{a}}$ \\
\hline \multirow[t]{2}{*}{ Island barley under-seeded red clover } & LF & $15.7^{\mathrm{a}}$ & $0.05^{\mathrm{a}}$ \\
\hline & S & $15.1^{\mathrm{a}}$ & $0.04^{\mathrm{a}}$ \\
\hline Year 2 & $\mathrm{EF}$ & $38.9^{\mathrm{a}}$ & $0.06^{\mathrm{a}}$ \\
\hline \multirow[t]{2}{*}{ Red clover } & LF & $41.7^{\mathrm{a}}$ & $0.06^{\mathrm{a}}$ \\
\hline & S & $35.7^{\mathrm{a}}$ & $0.05^{\mathrm{a}}$ \\
\hline Year 3 & $\mathrm{EF}$ & $71.1^{5^{-}}$ & $0.7^{b^{-}}$ \\
\hline \multirow[t]{2}{*}{ Potato (Russet Burbank) } & LF & $71.9^{\mathrm{b}}$ & $0.7^{\mathrm{b}}$ \\
\hline & S & $116.5^{\mathrm{a}}$ & $1.2^{\mathrm{a}}$ \\
\hline
\end{tabular}

*Note. LF plowing was based on the $7{ }^{\circ} \mathrm{C}$ temperature threshold for 5 consecutive days. ${ }^{\mathrm{z}}$ Numbers with the same letter are not significantly different at the probability level of 0.05 .

$\mathrm{Gu}$ et al. (2013), and Rochette et al. (2018) found that fine textured soils have a greater potential for $\mathrm{N}_{2} \mathrm{O}$ emissions. Rochette et al. (2018) found that $\mathrm{N}_{2} \mathrm{O}$ emissions were 3-5 times higher in fine texture and poorly drained soils compared to dry coarse textured soils. Fluxes in the present study were similar to ranges found by Smith et al. (2008) when measuring losses from agricultural soils following manure application on similar soils. Velthof et al. (2010) reported that $\mathrm{N}_{2} \mathrm{O}$ emissions were higher on the clay soils compared to the sandy soils where grasslands were being maintained. Hao et al. (2001) and Venterea et al. (2005) also had similar findings when $\mathrm{N}_{2} \mathrm{O}$ was measured following varying tillage and fertilizer management. Acidic soils have also been found 
to be an indicator of lower overall $\mathrm{N}_{2} \mathrm{O}$ emissions, while increasing the $\mathrm{N}_{2} \mathrm{O}: \mathrm{N}_{2}$ ratio (Liu et al., 2010), as also indicated in the present study where soils were found to have a pH of 5.8-6.1 throughout the study period.

Nitrous oxide levels were variable throughout the study. It should be noted that measurements obtained over different types of cropping years with different inputs may produce variable results. The sporadic nature of $\mathrm{N}_{2} \mathrm{O}$ fluxes from agricultural soils is a challenge to its measurement, but increased replications as used in the present study helped to account for these differences. Total losses were also low in all rotation periods studied; EF: 16.4, LF: 15.7 and S: $15.1 \mathrm{~g}$ of $\mathrm{N} \mathrm{ha}^{-1}$ in yr 1; EF: 38.9, LF: 41.7 and S: $35.7 \mathrm{~g} \mathrm{of} \mathrm{N} \mathrm{ha}^{-1}$ in yr 2; and EF: 71.1, LF: 71.9 and $\mathrm{S}: 116.5 \mathrm{~g}_{\text {of }} \mathrm{N} \mathrm{ha}^{-1}$ in yr 3 (Table 4). In the present study, moderate peak increases in emissions were found following fertilizer application in all years studied; this finding was similar to Thorton et al. (1996), Venterea and Rolston (2000), Venterea et al. (2005), Smith et al. (2008), and Fernandez et al. (2016). Fernandez et al. (2016) attributed large fluxes due to the timing of fertilizer application coupled with high precipitation rates and found reduced $\mathrm{N}_{2} \mathrm{O}$ emissions when corn received split $\mathrm{N}$ applications instead of a single pre-plant application. Losses in the present study were reduced for the remainder of the growing season shortly following fertilizer application. Cumulative $\mathrm{N}_{2} \mathrm{O}$ losses were found to be highest in yr 3; this was most likely attributable to the incorporation of red clover from yr 2; as well as the plots received $100 \mathrm{~kg} \mathrm{~N} \mathrm{ha}^{-1}$ at the time of seeding. The red clover would have introduced a source of N. Gregorich et al. (2005) found that systems containing legumes produced lower $\mathrm{N}_{2} \mathrm{O}$ emissions annually compared to fertilized annual crops, suggesting that alfalfa and other legume forage crops should be categorized differently from other crops when deriving national inventories for agricultural systems. This difference is most likely related to the acceleration of $\mathrm{N}$ mineralization associated with the difference in tillage practice; for instance annual cropping systems are typically moldboard plowed, whereas perennial systems are not. In the present study, when red clover was incorporated into the soil in the spring of yr $3 \mathrm{~N}_{2} \mathrm{O}$ emissions were found to increase afterwards, as also seen in Chantigny et al. (2002). This was most likely due to an increase in available $\mathrm{N}$.

Venterea et al. (2005) also found low $\mathrm{N}_{2} \mathrm{O}$ fluxes (10-100 $\mu \mathrm{g} \mathrm{N} \mathrm{m}^{-2} \mathrm{~h}^{-1}$ ) from no, minimum and conventional till systems. Venterea et al. (2005) and Aulakh et al. (1984) found that no/zero and minimum till had higher $\mathrm{N}_{2} \mathrm{O}$ fluxes compared to conventional tillage and attributed this to reduced soil pore space and increased soil moisture in these systems promoting denitrification. Overall findings in the present study, showed no statistical differences between $\mathrm{N}_{2} \mathrm{O}$ total loss $\left(\mathrm{g} \mathrm{N} \mathrm{ha}^{-1}\right.$ as indicated in Table 4) and the plow times in yr 1 and 2, however, in yr $3 \mathrm{~S}$ plow was found to be higher than EF and LF, most likely due to increased soil moisture, as well as incorporation of the red clover $\mathrm{N}$ source. Contrary to yr 3 in the present study, Datta et al. (2013) found no $\mathrm{N}_{2} \mathrm{O}$ flux differences when looking at both the effects of tillage and drainage management.

Overall, $\mathrm{N}_{2} \mathrm{O}$ losses in the present study accounted for $0.04-1.2 \%$ of the $\mathrm{N}$ applied in all cropping seasons. These results fall within the range of 0.001-6.84\% found by Eichner (1990) who evaluated losses from N fertilized soils. Losses in the present study were however, lower than the assumed $1.25 \%$ of the applied $\mathrm{N}$ (in the form of fertilizer) that the Intergovernmental Panel on Climate Change (2006) uses as a guideline for calculating emissions. It is therefore recommended that on-farm management practices should also be considered when determining emission factors. Measuring dissolved $\mathrm{N}_{2} \mathrm{O}$ emissions from each plow time drain may have resulted in differing results and should be explored in the future.

\subsection{Yields}

Barley yields in yr 1 were comparable for all plots at; 3.9, 4.0, $3.9 \mathrm{t} \mathrm{ha}^{-1}$ for EF, LF and S respectively, with no differences found. In yr 1, the plots were sown to barley and under-seeded to red clover and the plots received a uniform application of $\mathrm{N}$. However, in order to ascertain that there was no carry over effect of the potatoes on soil $\mathrm{N}$ status, barley yield was determined from the areas in each plot that had received no $\mathrm{N}$ fertilizer the previous year. Barley yields indicate that there was no effect of plowing or $\mathrm{N}$ treatments on overall yields indicating that there was limited $\mathrm{N}$ carryover from the previous year.

Red clover samples were obtained for yield calculations on Oct. 4 and Nov. 14 in yr 2. Total average yields on Oct. 4 were; 3.8, 3.7 and $3.8 \mathrm{tha}^{-1}$ for EF, LF and S, respectively. Total average yields on Nov. 4 were 3.4 and $3.3 \mathrm{t} \mathrm{ha}^{-1}$ for LF and S, respectively. Early fall yields could not be calculated on Nov. 14 as these plots were previously plowed on Oct. $6^{\text {th }}$. Red clover plow down acted as a green manure contributing $70 \mathrm{~kg} \mathrm{~N}^{-1}$. Results overall indicated that there were no differences in red clover yields between the different plow times.

Total Russet Burbank potato yields for yr 3 were found to be 24.2 and 26.0 and $24.0 \mathrm{t} \mathrm{ha}^{-1}$ for EF, LF and S plowing, respectively. When looking at overall total yields there were apparent trends between treatments most likely due to early die down, drought, and Verticillium wilt. When examining the yields at the $10 \mathrm{oz}$ size however, there were significant differences found. The $10 \mathrm{oz}$ yields were found to be at least double in the LF 
$\left(0.73 \mathrm{t} \mathrm{ha}^{-1}\right)$ when compared to EF $\left(0.34 \mathrm{tha}^{-1}\right)$ and $\mathrm{S}\left(0.25 \mathrm{t} \mathrm{ha}^{-1}\right)$ yields. This finding would suggest that LF plowing was beneficial when going into potato production.

\section{Conclusion}

Subsurface drainage systems were found to be effective at water management throughout all cropping years, producing good overall crop yields. Reducing the simultaneous $\mathrm{N}$ losses of $\mathrm{NO}_{3}^{-}-\mathrm{N}$ and $\mathrm{N}_{2} \mathrm{O}$ from tile-drained fields is important to the overall on-farm nutrient management, as well as the surrounding environment. Losses of total $\mathrm{NO}_{3}{ }^{-}-\mathrm{N}$ loads exiting the drainage systems over the monitoring periods were 22,15 and $23 \%$ of the applied $\mathrm{N}$ loss in yr 1; 7.4, 2.4 and 3.3\% of the applied $\mathrm{N}$ loss in yr 2; and 11.7, 7.7, and 10.0\% of the applied $\mathrm{N}$ loss in yr 3 for EF, $\mathrm{LF}$, and $\mathrm{S}$ respectively. Overall, $\mathrm{NO}_{3}{ }^{-} \mathrm{N}$ loads for the 3 yr potato rotation were reduced at 14.3 and $19.9 \mathrm{~kg} \mathrm{ha}^{-1}$ for LF and S respectively, when compared to the EF plow at $24.4 \mathrm{~kg} \mathrm{ha}^{-1}$. Nitrous oxide emissions were variable throughout each cropping year with increased emissions following manure, fertilizer applications and legume incorporation. Total losses of $\mathrm{N}_{2} \mathrm{O}$ were found to be higher in the $\mathrm{S}$ plots when compared to EF and LF plowing of red clover for the potato production year. Overall, total $\mathrm{N}_{2} \mathrm{O}$ losses were found to be $0.04-1.2 \%$ of the applied $\mathrm{N}$ throughout the study. Although $\mathrm{N}_{2} \mathrm{O}$ losses were relatively low throughout the study period it is important to note that these are still agro-economic losses which also have the potential to contribute to stratospheric ozone depletion and the greenhouse effect. Management practices should be considered when determining overall emission factors.

This study suggested that plow timing based on temperature could be considered as a management practice when trying to minimize overall $\mathrm{N}$ losses via water and air in a $3 \mathrm{yr}$ potato production system. Although the differences in $\mathrm{NO}_{3}{ }^{-}-\mathrm{N}$ loading between $\mathrm{S}$ and LF plowing were found to be minimal, $\mathrm{LF}$ was found to reduce $\mathrm{N}_{2} \mathrm{O}$ emissions compared to $\mathrm{S}$ in 1 year of the study, and LF plowing also provided good yields with a 3 times increase in the amount of larger $10 \mathrm{oz}$ more marketable potatoes vs $\mathrm{S}$ plowing. Research findings will be beneficial for producers, nutrient management and environmental farm planners. Findings will aid in minimizing nutrient, environmental and economic losses for producers across the region without compromising overall crop quality and yield. The trade-off between $\mathrm{NO}_{3}{ }^{-}-\mathrm{N}$ and $\mathrm{N}_{2} \mathrm{O}$ was minimal in the present study, suggesting more focus should be placed on minimizing $\mathrm{NO}_{3}{ }^{-} \mathrm{N}$ losses and the future measurement of dissolved $\mathrm{N}_{2} \mathrm{O}$ from the drainage water under similar systems may also provide additional information.

\section{Acknowledgements}

The authors would like to gratefully acknowledge Agriculture and Agri-Food Canada (AAFC) and St. Francis Xavier University for supporting this research. Special thanks to Becky McDonald, Roger Henry and Sandy Jenkins for all their valuable technical expertise and effort; and thanks to all the AAFC summer students who have helped with field sampling throughout the duration of this research; Emily Davis, Clara Wood and Ella Wood.

\section{References}

AAFC. (2014). Flexibility of no till and reduced till systems ensures success in the long term. Retrieved from http://www.agr.gc.ca/eng/science-and-innovation/agricultural-practices/soil-and-land/soil-management/flexi bility-of-no-till-and-reduced-till-systems-ensures-success-in-the-long-term/?id=1219778199286

Agilent Technologies. (2005). Varian Star 3800 Gas chromatography. Retrieved from https://www.agilent.com/ cs/library/usermanuals/Public/914731_R6.pdf

Aulakah, M. S., Rennie, D. A., \& Paul, E. A. (1984). Gaseous nitrogen losses from soils under zero-till management systems. J. Environ. Qual., 13(1), 130-136. https://doi.org/10.2134/jeq1984.131130x

Blackmer, A., \& Bremner, J. (1978). Inhibitory effect of nitrate on reduction of $\mathrm{N}_{2} \mathrm{O}$ to $\mathrm{N}_{2}$ by soil microorganisms. Soil Biol. Biochem., 10(3), 187-191. https://doi.org/10.1016/0038-0717(78)90095-0

Butterbach-Bahl, K., Baggs, E. M., Dannenmann, M., Kiese, R., \& Zechmeister- Boltenstern, S. (2013). Nitrous oxide emissions from soils: how well do we understand the processes and their controls? Phil. Trans. R. Soc. B, 368. https://doi.org/10.1098/rstb.2013.0122

Camara, K. M., Payne, W. A., \& Rasmussen, P. E. (2003). Long-term effects of tillage, nitrogen, and rainfall on winter wheat yields in the Pacific Northwest. Am. Soc. Agron., 95, 828-835. https://doi.org/10.2134/agronj 2003.0828

Chantigny, M. H., Rochette, P., \& Angers, D. A. (2002). The fate of carbon and nitrogen from different organic residues in wet and cold soils. Soil Biol. Biochem., 34, 509-517. https://doi.org/10.1016/S0038-0717 (01)00209-7 
Collier, S. M., Ruark, M. D., Oates, L. G., Jokela, W. E., \& Dell, C. J. (2014). Measurement of greenhouse gas flux from agricultural soils using static chambers. J. Vis. Exp., 90. https://doi.org/10.3791/52110

Datta, A., Smith, P., \& Lal, R. (2013). Effects of long-term tillage and drainage treatments on greenhouse gas fluxes from a corn field during the fallow period. Agric. Ecosyst. Environ., 171, 112-123. https://doi.org/ 10.1016/j.agee.2013.03.014

Di, H. J., \& Cameron, K. C. (2002). Nitrate leaching in temperate agroecosystems: Sources, factors and mitigating strategies. Nutr. Cycl. Agroecosys., 46, 237-256. https://doi.org/10.1023/A:1021471531188

Donner, S. D., \& Kucharik, C. J. (2003). Evacuating the impacts of land management and climate variability on crop production and nitrate export across the upper Mississippi basin. Global Biogeochem. Cycles, 17(3), 1085. https://doi.org/10.1029/2001GB001808

Eichner, M. J. (1990). Nitrous oxide emissions from fertilized soils: Summary of available data. J. Environ. Qual., 19, 272-280. https://doi.org/10.2134/jeq1990.192272x

Elmi, A., Burton, D., Gordon, R., \& Madramootoo, C. (2005). Impacts of water table management on $\mathrm{N}_{2} \mathrm{O}$ and $\mathrm{N}_{2}$ from a sandy loam in southwestern Quebec, Canada. Nutr. Cycl. Agroecosys, 72(3), 229-240. https://doi.org/10.1007/s10705-005-2920-9

Environment and Climate Change Canada. (2017). National inventory report 1990-2015: Greenhouse gas source and sinks in Canada (p. 351). Canada's submission to the United Nations framework convention on climate change. Environment and Climate Change Canada, Gatineau, Quebec, Canada.

Environment and Climate Change Canada. (2018). Historical data-station results. Retrieved from http://climate.weather.gc.ca/historical_data/search_historic_data_stations_e.html?StationID=50621\&Month $=8 \&$ Day $=22 \&$ Year $=2018 \&$ timeframe $=2 \&$ StartYear $=1840 \&$ EndYear $=2018 \&$ searchType $=$ stnProx \&txtRadi us $=25 \&$ optProxType $=$ navLink\&txtLatDecDeg=46.289166666667\&txtLongDecDeg=63.119166666667\&o ptLimit $=$ specDate \&selRowPerPage $=25 \&$ station $=$ CHARLOTTETOWN + A

Fernandez, F. G,. Venterea, R. T., \& Fabrizzi, K. P. (2016). Corn nitrogen management influences nitrous oxide emissions in drained and undrained soils. J. Environ. Qual., 87, 229-240. https://doi.org/10.2134/jeq201 6.06 .0237

Galloway, J. N., \& Cowling, E. B. (2002). Reactive nitrogen and the world: 200 years of change. J. Human Environ., 31(2), 64-71. https://doi.org/10.1579/0044-7447-31.2.64

Gartley, C., Cochrane, L., DeHaan, R., \& Madani, A. (1986). Farm drainage in the Atlantic provinces. A.C.A.E. Publication No. 3. Retrieved from http://nsfa-fane.ca/wp-content/uploads/ 2011/06/Farm-drainage.pdf

Gilliam, J. M., Skaggs, R. W., \& Weeds, S. B. (1979). Drainage control to diminish nitrate loss from agricultural fields. J. Environ. Qual., 8(1), 137-142. https://doi.org/10.2134/jeq1979.81137x

Gordon, R., Madani, A., Boyd, N., Astatkie, T., Jamieson, R., \& Caldwell, K. (2000). Subsurface nitrate-N leaching loss as affected by drainage size and depth in a shallow slowly-permeable soil. Can. Water Resour. J., 25(4), 331-341. https://doi.org/10.4296/cwrj2504331

Gregorich, E. G., Rochette, P., VandenBygaart, A. J., \& Angers, D. A. (2005). Greenhouse gas contributions of agricultural soils and potential mitigation practices in Eastern Canada. Soil Tillage Res., 83, 53-72. https://doi.org/10.1016/j.still.2005.02.009

Gu, J., Nicoullaud, B., Rochelle, P., Grossel, A., Henault, C., Cellier, P., \& Richard, G. (2013). A regional soil experiment suggests that soil texture is a major control of $\mathrm{N}_{2} \mathrm{O}$ emissions from tile-drained winter wheat fields during the fertilization period. Soil Bio. Biochem., 60, 134-141. https://doi.org/10.1016/j.soilbio. 2013.01.029

Hao, X., Chang, C., Carefoot, J. M., Janzen, H. H., \& Ellert, B. H. (2001). Nitrous oxide emissions from an irrigated soil as affected by fertilizer and straw management. Nutr. Cycl. Agroecosys., 60, 1-8. https://doi.org/10.1023/A:1012603732435

Health Canada. (2015). Guidelines for Canadian drinking water quality. Ottawa, ON, Canada: Health Canada.

Intergovernmental Panel on Climate Change. (2006). In H. S. Eggleston, L. Buendia, K. Miwa, T. Ngara, \& K. Tanabe (Eds.), 2006 IPCC Guidelines for National Greenhouse Gas Inventories. Prepared by the National Greenhouse Gas Inventories Programme, IGES, Japan. 
Jaynes, D. B., Colvin, T. S., Karlen, D. L., Cambardella, C. A., \& Meek, D. W. (2001). Nitrate loss in subsurface drainage as affected by nitrogen fertilizer rate. J. Environ. Qual, 30, 1305-1314. https://doi.org/10.2134/ jeq2001.3041305x

Jiang, Y., Jamieson, T., Nyiraneza, J., Somers, G., Thompson, B., Murray, B., Grimmett, M., \& Geng, X. (2015). Effects of fall vs. spring plowing forages on nitrate leaching losses to groundwater. Ground Water Monit. Rem., 35, 43-54. https://doi.org/10.1111/gwmr.12083

Kellman, L. M. (2005). A study of tile drain nitrate values as a toll for assessing nitrate sources in an agricultural region. Nutr. Cycl. Agroecosys., 71, 131-137. https://doi.org/10.1007/s10705-004-1925-0

Lachat Instruments. (2013). Quikchem 8500 Series 2 Flow Injection Analysis system. Retrieved from http://www.lachatinstruments.com/products/quik-chem-flow-injection-analysis/quikchem-fia.asp

Lamb, J. A., Fernandez, F. G., \& Kaiser, D. E. (2014). Understanding nitrogen in soils. Retrieved from http://www.extension.umn.edu/agriculture/nutrient-management/nitrogen/understanding-nitrogen-in-soils/d ocs/AG-FO-3770-B.pdf

Liu, B., Morkved, P., Frostegard, A., \& Bakken, L. (2010). Denitrification gene pools, transcription and kinetics of $\mathrm{NO}, \mathrm{N}_{2} \mathrm{O}$ and $\mathrm{N}_{2}$ production as affected by soil pH. Fed. Eur. Microbiol. Soc., 72(3), 407-417. https://doi.org/10.1111/j.1574-6941.2010.00856.x

MacDougall, J. I., Veer, C., \& Wilson, F. (1988). Soils of Prince Edward Island (p. 210). Contribution No. 83-54. Supply and Services Canada. Research Branch, Agriculture and Agri-Food Canada, Land Resource Research Centre, Ottawa, ON.

Malhi, S. S., McGill, W. B., \& Nyborg, M. (1990). Nitrate losses in soils: Effect of temperature, moisture and substrate concentration. Soil Biol Biochem, 22(6), 733-737. https://doi.org/10.1016/0038-0717(90)90150-X

Minitab. (2008). Minitab version 15. Minitab Inc. State College, PA.

Myhre, G., Shindell, D., Bréon, F.-M., Collins, W., Fuglestvedt, J., Huang, J., Koch, D., ... Zhang, H. (2013). Anthropogenic and Natural Radiative Forcing. In T. F. Stocker, D. Qin, G. K. Plattner, M. Tignor, S. K. Allen, J. Boschung, ... P. M. Midgley (Eds.), Climate Change 2013: The Physical Science Basis. Contribution of Working Group I to the Fifth Assessment Report of the Intergovernmental Panel on Climate Change. Cambridge University Press, Cambridge, United Kingdom and New York, NY, USA.

Prince Edward Island Potato Board. (2017). Retrieved from https://www.peipotato.org/pei-potato-industry

Randall, G. W., \& Iragavarapu, T. K. (1995). Impacts of long-term tillage systems for continuous corn on nitrate leaching to tile drainage. J. Environ. Qual., 24, 360-366. https://doi.org/10.2134/jeq1995.004724250024000 20020x

Raper, R. L., Reeves, D. W., Burmester, C. H., \& Schwab, E. B. (2000). Tillage depth, tillage timing, and cover crop effects on cotton yield, soil strength and tillage energy requirements. Am. Soc. Agr. Eng., 16(4), 379-385. https://doi.org/10.13031/2013.5363

Rasouli, S., Whalen, J., \& Madromootoo, C. (2014). Review: Reducing residual soil nitrogen losses from agroecosystems for surface water protection in Quebec and Ontario, Canada: Best management practices, policies and perspectives. Can. J. Soil Sci., 94, 109-127. https://doi.org/10.4141/cjss2013-015

Reicosky, D. C. (2006). Tillage and gas exchange. Ency. Soil Sci., 1771-1775. https://doi.org/10.1081/ E-ESS-120042769

Robertson, G. P. (2014). Soil greenhouse gas emissions and their mitigation. Ency. Agr. Food Syst, 5, 185-186. https://doi.org/10.1016/B978-0-444-52512-3.00097-8

Rochette, P., Liang, C., Pelster, D., Bergeron, O., Lemke, R., Kroebel, R., ... Flemming, C. (2018). Soil nitrous oxide emissions from agricultural soils in Canada: Exploring relationships with soil, crop and climatic variables. Agric. Ecosyst. Environ., 254, 69-81. https://doi.org/10.1016/j.agee.2017.10.021

Sanderson, J. B., MacLeod, J. A., \& Kimpinski, J. (1999). Glyphosphate application and timing of tillage of red clover affects potato response to N, soil N profile, and root and soil nematodes. Can. J. Soil Sci., 79(1), 65-72. https://doi.org/10.4141/S98-028

Sands, G. R., Song, I., Busman, L. M., \& Hansen, B. J. (2008). The effects of subsurface drainage depth intensity on nitrate loads in the northern corn belt. Am. Soc. Agr. Biol. Eng., 51(3), 937-946. https://doi.org/ $10.13031 / 2013.24532$ 
Schlesinger, W. H., \& Bernhardt, E. S. (2013). Biogeochemistry: An analysis of global change (Chap. 12). The global cycles of nitrogen and phosphorous (pp. 445-467). Academic Press.

Shepard, M. A., Davies, D. B., \& Johnson, P. A. (1993). Minimizing nitrate losses from arable soils. Soil Use Manage, 9(3), 94-99. https://doi.org/10.1111/j.1475-2743.1993.tb00936.x

Smith, E. L., \& Kellman, L. M. (2011). Examination of nitrate concentration, loading and isotope dynamics in subsurface drainage under standard agricultural cropping in Atlantic Canada. J. Environ. Manage, 92, 2892-2899. https://doi.org/10.1016/j.jenvman.2011.06.043

Smith, E., Gordon, R., Bourque, C., \& Campbell, A. (2008). Management strategies to simultaneously reduce ammonia, nitrous oxide and odour emissions from surface-applied swine manure. Can. J. Soil Sci., 88, 571-574. https://doi.org/10.4141/CJSS07089

Snowdon, E., Zebarth, B. J., Burton, D. L., Goyer, C., \& Rochette, P. (2013). Growing season $\mathrm{N}_{2} \mathrm{O}$ emissions from two-year potato rotations in a humid environment in New Brunswick, Canada. Can. J. Soil Sci., 93, 279-294. https://doi.org/10.4141/cjss2012-115

Thorton, F., Bock, B., \& Tyler, D. (1996). Soil emissions of nitric oxide and nitrous oxide from injected anhydrous ammonia and urea. J. Environ. Qual., 25, 1378-1384. https://doi.org/10.2134/jeq1996.2561378x

Tomer, M. D., Meek, D. W., Jaynes, D. B., \& Hatfield, J. L. (2003). Evaluation of nitrate nitrogen fluxes from a tile-drained watershed in Central Iowa. J. Environ. Qual., 32, 642-653. https://doi.org/10.2134/jeq2003.6 420

Velthof, G. L., Hoving, I. E., Dolfing, J., Smit, A., Kuikman, P. J., \& Oenema, O. (2010). Method and timing of grassland renovation affects herbage yield, nitrate leaching and nitrous oxide emission in intensively managed grasslands. Nutr. Cycl. Agroecosys., 86, 401-412. https://doi.org/10.1007/s10705-009-9302-7

Venterea, R. T., \& Rolston, D. E. (2000). Mechanisms and kinetics of nitric and nitrous oxide production during nitrification in agricultural soil. Global Change Biol., 6, 303-316. https://doi.org/10.1046/j.1365-2486.2 000.00309.x

Venterea, R. T., Burger, M., \& Spokas, K. A. (2005). Nitrogen oxide and methane emissions under varying tillage and fertilizer management. J. Environ. Qual., 34, 1467-1477. https://doi.org/10.2134/jeq2005.0018

Wesström, I., \& Messing, I. (2007). Effects of controlled drainage on N and P losses and N dynamics in a loamy sand with spring crops. Agric. Water Manage, 87, 229-240. https://doi.org/10.1016/j.agwat.2006.07.005

Xue, Y., Van Es, H., Schindelbeck, R., Moebius-Clune, B., Melkonian, J., Graham, C., \& Yang, P. (2013). Effects of $\mathrm{N}$ placement, carbon distribution and temperature on $\mathrm{N}_{2} \mathrm{O}$ emissions in clay loam and loamy sand soils. Soil Use Manage, 29, 240-249. https://doi.org/10.1111/sum.12037

Yost, M. A., Coulter, J. A., Russelle, M. P., Sheaffer, C. C., \& Kaiser, D. E. (2012). Alfalfa nitrogen credit to first-year corn: Potassium, regrowth and tillage timing effects. Agron. J., 104(4), 953-962. https://doi.org/10.2134/agronj2011.0384

\section{Copyrights}

Copyright for this article is retained by the author(s), with first publication rights granted to the journal.

This is an open-access article distributed under the terms and conditions of the Creative Commons Attribution license (http://creativecommons.org/licenses/by/4.0/). 